\title{
下河内 稔 先生を偲んで
}

大阪大学大学院人間科学研究科

$$
\text { 入戸野 宏 }
$$

日本の事象関連電位研究の先駆者であり, 本学会の設立にも貢献されました下河内稔 先生が 2021 年 10 月 25 日に 94 歳で永眠なさいました。謹んで哀悼の意を表しますととも に, 先生のご略歴と個人的な思い出を紹介させていただきます。

下河内先生は, 1927 年 8 月 26 日に兵庫県にお生まれになりました。大阪大学医学部在 学中から, 第 2 生理学教室の吉井直三郎先生の指導を受けられました。吉井先生は, 戦後 まもなく脳波や筋電図を測定する研究を行い, 条件反射を活用して行動と脳機能の関係を 分析する精神生理学の開拓に尽くされた方です（河村, 1997）。その吉井先生の下で，下 河内先生は 1960 年から助手を務め, イ邓の古典的条件つけについての脳波学的研究など を行いました。さらに, 1964 年 9 月から 2 年間, 第 1 回フルブライト奨学生としてニュー ヨーク医科大学の E. R. John 博士のもとに留学されました。主に, ネコの慢性深部記録電 極を用いた誘発電位研究に従事し, 記憶の読み出しにかかわる電位を Science 誌等で発表 されました。1964 年 10 月 23 日に, 同じニューヨークにいた Samuel Sutton 博士のセミナ ーをコロンビア大学で聞き, ヒトの脳波から測定する P300 の存在を知ります。帰国後 は, 新設された大阪大学医療技術短期大学部（現在は廃止）に教授として就任され, 認知 に関する誘発電位（事象関連電位）の研究を始めます。さらに，1974 年には同大学人間 科学部行動生理学講座の初代教授に着任します。ヒトの事象関連電位の研究とともに, 動 物の研究（特に性行動）も並行して行われました。性行動をテーマにしたのは, 人間科学 部では個体にとどまらず社会的関係に注目するのがよいだろうというお考えに基づくもの でした。1991 年3月に大阪大学を定年退官された後は, 甲子園短期大学教授として 5 年間 教鞭をとられました。このあたりの経緯については, 本学会の30 周年特集号「我が国に おける生理心理学と学会の歩み」に先生ご自身がお書きになっています（下河内, 2012)

下河内先生は, 私が学部 3 年生で研究室配属になる直前に退官されましたので, 直接ご 指導いただくことはかないませんでした。先生とともに事象関連電位研究の普及に貢献さ れた投石保広先生（助手，のちに講師）の下で, 事象関連電位の基礎を学びましたので, 孫弟子にあたります。学部生のころは, 先生が業者とともに開発された初代のシグナルプ ロセッサー（三栄測器製 7T17）を使っていました。当時でも珍しかった 8 イチのフロ 
生理心理学と精神生理学 (J-STAGE での早期公開＼cjkstart公開日：2021/12/15)

この記事は早期公開したものです。後日，巻・号・開始ページ等が確定した時点で正式公開されます。

Japanese Journal of Physiological Psychology and Psychophysiology

(Advance Publication by J-STAGE Date: 2021/12/15)

This is an article published online as advance publication. It will be re-published when its bibliographical information (volume, number, issue number, starting page, and so on) is determined.

ッピーディスクが記録媒体だったのが印象的でした。私が大学院生だった 1990 年代で も, 脳波や事象関連電位は心理学の中では市民権が得られておらず，極めてマイナーな分 野でした。大脳生理学がご専門であった先生が，心理学に近い分野で研究を行うことには さぞ苦労が多かっただろうと想像します。事象関連電位の国際会議 EPIC（Evoked Potentials International Conference）を日本に誘致することにもご尽力され，1995 年 6 月 25 -30日に第 11 回大会が沖縄で盛大に開催されました。私が M2 のときで, 最初に発表し た国際学会でした。著名な研究者が多数来日され, 私の恩師である Peter Ullsperger 先生に 初めてお会いしたのもその学会でした。

退官後もときおり研究室の夏合宿でお目にかかり，一緒にテニスをさせていただきま した。先生は本当にテニスがお上手で, 学生ソフトテニス連盟にも長い間かかわっておら れました。がっしりとした体格で,「豪放否落」という言葉がぴったりするスポーツマン でした。

その後, 私が広島大学に務めているときに，たまたま近くにお越しになるということ で『事象関連電位研究の黎明期』という講演をしていただきました（2009年 7 月 1 日）。 当時の実験映像を 8 ミリ映写機で流しながら, 研究の襄話をお聞かせくださいました。 2014 年には, 引退するからということで, 大量の蔵書と雑誌をお送りいただきました。

最後にお目にかかったのは，2016 年 4 月 27 日でした。大阪大学に着任した挨拶をする ため, ご自宅を訪問しました。脚を痛められで歩行が困難になっておられましたが，奥さ まとともに歓迎してくださいました。別れ際に，蔵書をプレゼントするから何でも持って いいといわれ，マグーンの『脳のはたらき』（時実利彦訳）を選んだところ，見返しにサ インをいただきました。

突然のお別れを寂しく思います。事象関連電位の伝統を受け継ぐものとして, 心ょり ご冥福をお祈りいたします。

\section{引用文献}

河村 洋二郎 (1997). 吉井直三郎先生を偲んで 日本生理学雑誌, 59, 336-337.

下河内 稔 (2012). 生理心理学会の思い出と EPIC 生理心理学と精神生理学, 30, 79-82. 
生理心理学と精神生理学 (J-STAGE での早期公開＼cjkstart公開日：2021/12/15)

この記事は早期公開したものです。後日，巻・号・開始ページ等が確定した時点で正式公開されます。

Japanese Journal of Physiological Psychology and Psychophysiology

(Advance Publication by J-STAGE Date: 2021/12/15)

This is an article published online as advance publication. It will be re-published when its bibliographical information (volume, number, issue number, starting page, and so on) is determined.

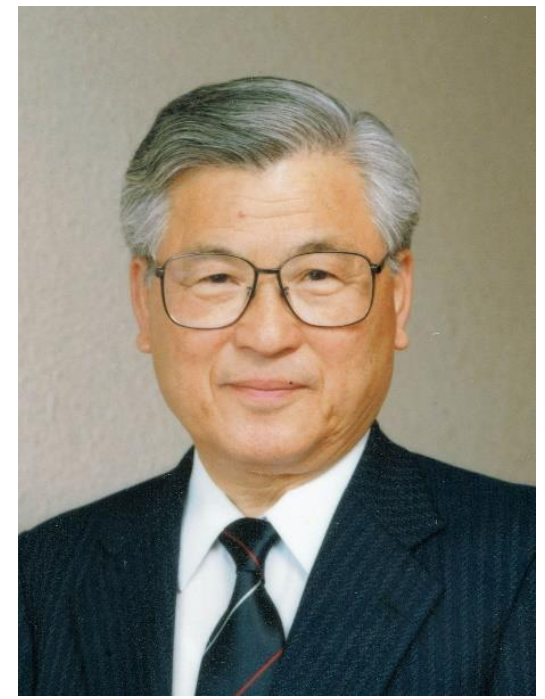

下河内 稔 先生 $(1927-2021)$ 